\title{
Internalization of Moral Values in the Frame of International School
}

\author{
Partono ${ }^{1}$, Wifda Untsa Nailufaz ${ }^{2}$, Uswatun Khasanah 3, Nur Anisa Amala \\ Widyastuti 4, Sinta Ulliyana Hidayatika 5 \\ DOI: $10.35445 /$ alishlah.v13i1.266
}

\begin{tabular}{l}
\hline Info Artikel \\
\hline Keywords: \\
Internalization \\
Moral Values \\
International School
\end{tabular}

Kata kunci:

Internalisasi

Nilai Moral

Sekolah Internasional

\begin{abstract}
This study aims to see how the process of internalizing moral values in Indonesian Foreign Schools, in this case, the Dutch Indonesian School in The Hague (SIDH). The research method used is descriptive qualitative with data collecting techniques such as interviews and documentation. The results showed that the moral values facilitated by SIDH include social values (which are reflected in honesty, responsibility, cooperation, tolerance, and peace, among others), religious values (which are reflected in obedience to worship and how to get along with the opposite sex by the teachings Islam). The value of nationalism (reflected in students while maintaining and introducing Indonesian culture in the Netherlands). Being present and developing in the Land of Windmills is not a barrier to continuing education by adhering to national values. Education does not deprive students of the roots of tradition or national moral values wherever education is located.
\end{abstract}

\footnotetext{
${ }^{1}$ Institut Agama Islam Negeri Kudus, Kudus, Indonesia

Email: partono@iainkudus.ac.id

2 Institut Agama Islam Negeri Kudus, Kudus, Indonesia

Email: wifdauntsa2001@gmail.com

3 Institut Agama Islam Negeri Kudus, Kudus, Indonesia

Email: uswaho4.kds@gmail.com

4 Institut Agama Islam Negeri Kudus, Kudus, Indonesia

Email: nuranisaamalawidyastuti@gmail.com

5 Institut Agama Islam Negeri Kudus, Kudus, Indonesia

Email: sintaulliyan@gmail.com

Vol.13 (1) June, 2021

Received: November 8, 2020; Received in revised form: January 18, 2021; Accepted: January 28, 2021; Available online: March 30, 2021

This is an open access article under a Creative Commons Attribution-NonCommercial-ShareAlike 4.0 International License
} 
pendidikan tidaklah mencabut peserta didik dari akar tradisi maupun nilainilai moral bangsa dimanapun pendidikan itu berada.

\section{PENDAHULUAN}

Di era 4.o ini, pendidikan nilai-nilai moral merupakan hal yang sangat penting untuk diajarkan kepada setiap peserta didik. Hal ini dikarenakan dengan semakin pesatnya teknologi informasi dan komunikasi di era sekarang yang menyebabkan berbagai macam tantangan dalam membentuk karakter peserta didik. Oleh sebab itu, dengan adanya pendidikan maka peserta didik diharapkan tetap memiliki moral yang baik. Sebagaimana yang telah dijelaskan dalam Undang-undang Sisdiknas no. 20 tahun 2003 pasal 1 ayat 1 bahwa pendidikan adalah usaha sadar dan terencana untuk mewujudkan suasana belajar dan proses pembelajaran yang menyenangkan agar peserta didik dapat secara aktif mengembangkan potensi dirinya untuk memiliki kekuatan spiritual keagamaan, pengendalian diri, kepribadian, kecerdasan, akhlak mulia, serta keterampilan yang diperlukan dirinya, masyarakat, bangsa dan negara. Tujuan dari sebuah pendidikan, yakni mampu menjadikan manusia yang beriman dan bertaqwa kepada Tuhan Yang Maha Esa, berakhlak mulia, berilmu, sehat, kreatif, cakap, mandiri, dan menjadi warga negara yang demokratis serta bertanggung jawab dapat tercapai secara maksimal sesuai dengan apa yang diharapkan (Noor, 2018).

Pendidikan menjadi salah satu indikator maju atau tidaknya suatu negara, karena masa depan sebuah negara dikatakan aman apabila berada ditengah masyarakat yang berpendidikan dan bermoral tinggi. Pendidikan akan terasa kurang lengkap apabila hanya mencetak lulusan yang hanya memiliki kecerdasan intelektual saja, tanpa diimbangi dengan kecerdasan dalam aspek afektif dan psikomotorik. Oleh karena itu, sebuah lembaga pendidikan tidak hanya dituntut untuk mengembangkan aspek kognitifnya saja, melainkan juga dituntut untuk mengembangkan aspek afektif dan psikomotorik dari peserta didik, agar dapat tumbuh menjadi manusia yang dilengkapi dengan moral yang tinggi, dan bertanggung jawab baik terhadap dirinya maupun terhadap lingkungan yang ada disekitarnya.

Jika ketiga aspek tersebut dapat berkembang secara seimbang, terutama aspek yang berkaitan dengan nilai moral, maka peserta didik diharapkan mampu menghadapi segala bentuk tantangan yang sudah ada di depan mata dengan bijak. Sebagaimana di lembaga pendidikan SIDH (Sekolah Indonesia Den Haag, Belanda). SIDH memiliki tantangan yang sangat besar, yakni bagaimana agar peserta didik tetap memiliki nilai-nilai moral sebagaimana nilai-nilai moral yang telah menjadi adat istiadat bangsa Indonesia. SIDH berusaha keras untuk tetap menanamkan nilai-nilai moral dengan menerapkan berbagai program sebagai bentuk upaya internalisasi nilai-nilai moral kepada peserta didik yang ada di SIDH. Adanya program internalisasi tersebut, diharapkan peserta didik dapat menampilkan sikap ataupun perilaku sesuai dengan nilai-nilai moral bangsa Indonesia.

Internalisasi merupakan sebuah proses penanaman nilai-nilai moral ke dalam diri pribadi peserta didik melalui proses binaan, bimbingan dan sebagainya, agar peserta didik mampu memahami serta mampu menghayati nilai-nilai moral yang ada, sehingga tercerminlah dalam sikap dan tingkah laku dari peserta didik (Lina, 2018). Adapun proses internalisasi yang dilakukan SIDH adalah dengan melalui pembiasaan perilaku yang sesuai dengan nilai-nilai moral bangsa Indonesia dalam kehidupan sehari-hari peserta didik tersebut, seperti pembiasaan sikap gotong royong dan toleransi dengan sesama.

Terkait dengan proses internalisasi nilai moral tersebut, Riyadi mengemukakan pendapatnya dalam penelitian sebelumnya bahwa terdapat metode lain yang bisa digunakan dalam proses menginternalisasikan nilai-nilai moral tersebut yakni metode tembang dolanan. Tembangtembang dolanan tersebut mengandung unsur-unsur pendidikan dan simbol-simbol kehidupan baik yang disampaikan secara tersurat maupun tersirat yang dapat dijadikan sebagai tuntunan bagi peserta didik dalam bertingkah laku. (Pujiastuti, 2015). Namun metode tersebut akan kurang efektif 
apabila diterapkan di SIDH secara keseluruhan, dimana melihat SIDH memiliki peserta didik yang lebih multikultural dibandingkan dengan peserta didik yang ada di Indonesia. Oleh karena itu SIDH berusaha untuk mengkolaborasikan beberapa metode pendekatan sebagai proses menginternalisasikan nilai-nilai moral tersebut kepada peserta didik. Tujuan dari proses ini untuk membentuk peserta didik yang memiliki karakter sebagaimana yang diharapkan oleh SIDH. SIDH tidak hanya berperan sebagai tempat untuk memberikan layanan pendidikan tetapi juga sebagai tempat untuk mempromosikan kebudayaan yang dimiliki oleh bangsa Indonesia kepada masyarakat internasional.

Penelitian ini dilakukan untuk mengetahui secara lebih mendalam mengenai bagaimana proses internalisasi nilai-nilai moral yang dilakukan SIDH kepada para peserta didiknya. Dari hasil penelitian yang diperoleh nantinya akan menjadi bahan evaluasi dan refleksi bagi SIDH tersebut dalam menghasilkan peserta didik yang berkarakter dengan mampu menampilkan sikap dan perilaku yang sesuai dengan adat istiadat bangsa Indonesia. Tentunya hal tersebut tidak mudah untuk dilakukan bahkan menjadi tantangan terbesar bagi SIDH, mengingat mereka hidup ditengah mayoritas masyarakat yang adat istiadatnya sangat jauh berbeda dengan adat istiadat bangsa Indonesia. Namun, hal tersebut tidak menghambat SIDH untuk tetap menjalankan peranannya dalam menanamkan nilai-nilai moral bangsa kepada peserta didiknya. Dengan demikian untuk mensukseskan proyek internalisasi nilai-nilai moral agar benar-benar dapat berhasil membutuhkan usaha yang keras terutama bagi seorang guru, karena guru dituntut untuk menjadi model dalam setiap perkataan dan perilakunya yang menyatu dalam kepribadiannya. Kepribadian merupakan suatu yang abstrak, sukar dilihat secara nyata, hanya dapat diketahui lewat penampilan, tindakan, dan ucapan, ketika peserta didik dihadapkan pada suatu persoalan (Muhammad Mahmud, 2018).

\section{METODE}

Metode penelitian yang digunakan dalam penilitian ini adalah deskriptif kualitatif. Yakni sebuah penelitian yang menggunakan lingkungan alamiah sebagai sumber datanya secara langsung. Dalam hal ini peneliti berusaha mencari data-data dengan menggali berbagai sumber yang terkait dengan fokus penelitian. Penulis mengumpulkan berbagai literatur dalam bentuk buku, jurnal, dokumentasi, hasil pengamatan, maupun hasil wawancara dengan ahli yang relevan dengan penelitian yang sedang dilakukan.

Penelitian deskriptif adalah sebuah metode penelitian yang berusaha memberikan gambaran maupun interpretasi atas suatu objek tertentu secara apa adanya sesuai dengan kondisi lapangan. Dalam penelitian ini penulis memberikan gambaran bagaimana kondisi lapangan dengan apa adanya tanpa melakukan perubahan angka ataupun simbol (kualitatif lapangan). Lebih lanjut lagi, secara spesifik tujuan penelitian ini untuk mengungkap bagaimana proses internalisasi nilai moral yang dilakukan SIDH (Sekolah Indonesia Den Haag).

Adapun sumber data yang digunakan dalam penelitian ini ada 2, yakni:

a. Sumber Data Primer

Data primer merupakan data yang diperoleh peneliti secara langsung. Dalam hal ini peneliti memperoleh data dari hasil wawancara, observasi dan dokumentasi dalam kegiatan KKL Virtual 2020 yang bekerjasama dengan pihak sekolah SIDH (Sekolah Indonesia Den Haag),

b. Sumber Data Sekunder

Data sekunder merupakan data yang diperoleh penulis dari berbagai sumber yang sudah ada. Dalam hal ini penulis memperoleh data dari literatur-literatur yang sudah ada, seperti; buku, jurnal, dan lain sebagainya yang berkaitan dengan topik penelitian yang sedang dilakukan.

\section{HASIL PENELITIAN DAN PEMBAHASAN}

\section{Nilai Moral yang Dikembangkan SIDH}

Nilai dimaknai sebagai sesuatu yang memberikan orientasi yang tetap kepada pribadi, kelompok, dan masyarakat untuk menghadapi situasi yang berbeda, bahkan belum pernah dijumpai sebelumnya sehingga mengokohkan integrasi sosial. Nilai dipandang sebagai sebuah motivasi dan 
orientasi yang diperlukan manusia sebagai pedoman dan menjelaskan sikap, norma, dan opini serta kendali tindakan manusia (Sanusi, 2017).

Nilai adalah sesuatu yang memberikan kemanfaatan serta diyakini kebenarannya dan mendorong manusia untuk melaksanakan serta mewujudkannya dalam kehidupan sehari-hari sebagai sebuah acuan dalam bertingkah laku (Boreza, 2015).Jika ditilik dari disiplin ilmu antropologi nilai dimaknai sebagai segala sesuatu yang berkaitan dengan budaya yang berkembang dalam sebuah masyarakat yang menjadi gambaran dari deskripsi hidupnya, bisa berwujud adat kebiasaan, keyakinan, bahasa, sampai pada institusi sosial yang berkembang di masyarakat (MASRUKHI, 2018).

Pengklasifikasian nilai ada tiga macam yaitu nilai materil,nilai vital, dan nilai kerohanian. Nilai materil merupakan semua hal yang dapat bermanfaat untuk manusia dari sisi jasmaninya. Sesuatu disebut memiliki nilai vital apabila bermanfaat untuk melakukan aktivitas manusia. Sesuatu disebut memiliki nilai kerohanian jika dapat bermanfaat untuk manusia dari sisi rohaninya. Berikutnya dalam nilai rohani diklasifikasikan menjadi 4 (Suyatno, 2012):

a. Nilai kenyataan atau kebenaran yang berasal dari akal sehat manusia.

b. Nilai keindahan yang berasal dari rasa (estetis) manusia, nilai kebaikan moral yang berasal pada kehendak (karsa) manusia.

c. Nilai kebaikan (nilai moral) yang berasal dari kehendak karsa, karsa hati nurani manusia.

d. Nilai religius yang berasal dari keimanan yang diikuti penghayatan melalui rasio dan budi manusia.

Moral dari sisi etimologis mempunyai beberapa makna diantaranya adat istiadat, cara hidup, dan kebiasaan. Dari pengertian tersebut, kata moral mempunyai kemiripan dengan kata ethos yang berasal dari bahasa Yunani yang pada perkembangannya dikenal dengan etik. Di samping itu, terdapat padanan kata yang memiliki makna yang sama dengan moral yakni akhlakyang berasal dari bahasa arab yakni kata khalaqa (khuluqun) yang berarti tabi'at, adat istiadat, atau kholqun yang berarti kejadian atau ciptaan.

Moralitas lebih sering dipadankan dengan etika. Kendati demikian, walaupun secara etimologis istilah moral memiliki makna suatu adat istiadat, kebiasaan, atau cara hidup, namun bukan berarti moralitas hanya terbatas pada tradisi atau istiadat saja. Lebih dari itu, moralitas berkaitan dengan baik buruk manusia. Moralitas menjadi sebuah parameter dalam menentukan benar atau tidaknya serta baik atau buruknya suatu perilaku manusia dilihat dari manusia sebagai 'manusia' dan bukan dilihat dari suatu lakon atau peran yang dijalankan. Dengan demikian, moral didalamnya mengandung muatan nilai dan norma yang bersumberkan pada hati nurani manusia.

Dari beberapa penjelasan di atas, peneliti menyimpulkan bahwa antara nilai dengan moral dapat ditarik sebuah perbedaan yang mana nilai dimiliki secara individual atau perorangan anggota masyarakat sedangkan moral adalah sebuah kesepakatan kolektif masyrakat terhadap tata nilai warganya dan dimiliki oleh masyarakat secara melembaga. Dalam konteks kebangsaan, maka nilai moral yang terkandung dalam masyarakat Indonesia tentu tidak lepas dari nilai moral pancasila. Oleh sebab berdiri di atas filosofi pancasila, bangsa Indonesia dengan kemajemukannya mampu hidup harmonis dan toleran. Tata nilai dan moral pancasila berfungsi sebagai pandangan hidup bangsa (way of life) sekaligus menjadi dasar negara Indonesia. Moral pancasila berarti kesusilaan dan adat menurut ajaran pancasila. Tata nilai pancasila berfungsi menjadi sebuah parameter perilaku masyarakatnya baik secara kolektif maupun individual. Setiap perbuatan dan tindakan manusia dianggap bermoral apabila telah sesuai dengan nilai-nilai yang terkandung dalam pancasila. Jadi, dalam proses berlangsungnya kehidupan bangsa Indonesia di dalamnya terdapat sebuah tolok ukur benar atau tidaknya perilaku masyarakat Indonesia dilihat dari kesesuaiannya dengan nilai-nilai pancasila. Sehingga, pancasila menjadi petunjuk arah atas semua kegiatan hidup dan kehidupan manusia Indonesia dalam berbagai bidang termasuk di dalamnya bidang pendidikan. 
Nilai moral yang telah dikembangkan oleh pihak SIDH (Sekolah Indonesia Den Haag) kepada para peserta didiknya, diantaranya adalah sebagai berikut:

a. Nilai Sosial

Nilai sosial dijadikan sebagai tolok ukur patut atau tidaknya suatu perilaku dalam kehidupan bermasyarakat. Nilai sosial menampilkan sampai sejauh mana ikatan antar individu dalam lingkup masyarakat. Keberadaan nilai sosial dalam lingkup masyarakat sangat terlihat nyata, salah satu contohnya adalah seperti gotong royong dan turut andil dalam kegiatan kemasyarakatan (Aisah, 2015).

Sekolah Indonesia Den Haag mengembangkan nilai sosial melalui perhatian SIDH terhadap pembentukan karakter para peserta didik, dimana muara akhirnya adalah karakter peserta didik tersebut akan dinilai dan dimasukkan ke dalam raport. Bila karakter tersebut tidak ada di dalam raport maka guru akan memberikan arahan serta bimbingan kepada para peserta didik sehingga pada akhirnya karakter peserta didik bisa berubah menjadi lebih baik. Karakter yang harus dimiliki oleh peserta didik di SIDH adalah bersikap jujur, tangung jawab, gotong royong, toleran, damai, santun, responsif dan percaya diri.

b. Nilai Keagamaan

Belanda mayoritas penduduknya adalah atheis. Oleh karena itu sebagai seorang pendidik tentulah harus membekali nilai-nilai keagamaan kepada para peserta didiknya. Muslim yang termasuk minoritasakan menghadapi banyak tantangan. Diantara tantangan-tantangan tersebut adalah sulit menemukan makanan ataupun minuman yang halal, minimnya tempat peribadatan, dan lain sebagainya.

Meskipun banyak tantangan yang muncul namun SIDH tetap mengajarkan dan menanamkan nilai-nilai keagamaan kepada para peserta didiknya, diantaranya adalah:

1) Selalu menunaikan shalat berjamaah.

2) Mengadakan kegiatan hafalan Al-Qur'an.

3) Mengajarkan bagaimana cara bergaul yang baik dengan lawan jenis. Karena di Belanda marak free sex, maka SIDH membuat keputusan dengan membuat peraturan yaitu dilarang berpacaran. Tujuan aturan ini adalah untuk memberikan benteng dan meminimalisir peserta didiknya agar tidak terjerumus ke dalam pergaulan bebas (free sex).

Pengajaran dan penanaman nilai-nilai keagamaan tersebut dapat berjalan dengan baik, karena pihak SIDH memberikan fasilitas kepada para peserta didiknya, seperti tempat wudhu, tempat beribadah (musala), Alquran serta alat beribadah yang lainnya.

c. Nilai Nasionalisme

Nasionalisme merupakan suatu paham terkait rasa cinta dan kesetiaan kepada tanah air. Nilai nasionalisme merupakan harapan dan cita-cita, untuk membangun masa depan bangsa yang harus memiliki rasa solidaritas, persatuan dan kesatuan, demokrasi, serta bangga dan setia terhadap bangsa dan negara. Mata pelajaran yang diharapkan mampu berkontribusi dalam menanamkan nilai-nilai nasionalisme kepada peserta didik diantaranya yaitu pendidikan kewarganegaraan, seni budaya, sejarah, dan bahasa Indonesia. Penanaman nilai nasionalisme di SIDH dapat terlihat saat mereka dijadikan sebagai duta budaya di Belanda. Hal ini terjadi karena peserta didik disana sering tampil membawakan dan memperkenalkan tarian budaya Indonesia dalam acara bergengsi yang diselenggarakan oleh beberapa organisasi yang ada di Belanda. Hal itulah yang membuat Indonesia dikenal oleh masyarakat Belanda.

\section{Proses Internalisasi Nilai Moral SIDH}

Proses internalisasi nilai moral yang dilakukan oleh SIDHdilakukan dengan berbagai macam pendekatan penanaman nilai (internalisasi). diantaranya adalah pendekatan pengalaman, pendekatan pembiasaan, pendekatan emosional, pendekatan rasional, pendekatan fungsional, dan pendekatan keteladanan. 
a. Pendekatan Emosional

Emosi merupakan sebuah gejolak psiko-fisiologis yang menimbulkan efek pada persepsi, sikap, dan tingkah laku, serta dalam bentuk ekspresi tertentu (Zulkarnain, 2019). Sementara menurut Muhtadi pendekatan emosional merupakan sebuah cara untuk membangkitkan perasaan dan emosi yang ada dalam diri siswa dalam hal meyakini, memahami dan menghayati konsep ajaran nilai-nilai moral yang ada serta dapat membedakan antara hal baik dan hal buruk (Muhtadi, 2007). Pendekatan emosional sangat sering digunakan dalam proses internalisasi nilai moral kepada peserta didik dalam sebuah lembaga pendidikan, tak terkecuali di SIDH (Sekolah Indonesia Den Haag). Pendekatan ini digunakan oleh para pendidik di SIDH ketika mereka harus menghadapi peserta didik yang bermasalah. Karena dengan menggunakan pendekatan ini harapan yang diinginkan oleh pendidik di SIDH akan lebih tersampaikan karena mereka berbicara dari hati ke hati. Pendekatan ini akan dapat mencapai hasil yang maksimal bahkan mampu menggugah perasaan dari peserta didik apabila stimulus yang diberikan oleh pendidik tersebut disesuaikan dengan kondisi dari peserta didik. Adapun stimulus yang diberikan dapat berupa verbal, seperti: cerita, sindiran, pujian, ejekan, berita, dialog, anjuran, perintah, larangan, dan sebagainya. Sedangkan yang non-verbal adalah berupa perilaku atau sikap guru yang dapat ditiru oleh peserta didik. Hal ini sejalan dengan yang dikemukakan oleh Darmiah (2019). Peserta didik akan mudah meniru hal-hal yang ditampilkan oleh pendidik yang mereka anggap model dalam proses pembelajaran.

Salah seorang pendidik di SIDH (Sekolah Indonesia Den Haag) memaparkan bahwa di SIDH diberlakukan sebuah peraturan yang melarang peserta didiknya berpacaran. Hal tersebut dilatarbelakangi oleh minimnya kontrol di negeri kincir angin yang menyebabkan pergaulan bebas antara laki-laki dan perempuan. Remaja yang berumur 14 tahun telah diberi vaksin kanker serviks karena di umur 14 tahun remaja telah sampai pada tahap sexually active dan didorong pula oleh lingkungan di Negara Belanda yang bebas. Berangkat dari fakta tersebut, SIDH sebagai lembaga pendidikan Indonesia yang tidak lepas dari moral pancasila dimana didalamnya terdapat nilai ketuhanan maka diangkatlah peraturan dilarangnya pacaran untuk mengakomodir nilai moral pancasila ke dalam diri siswa. Sehingga, manakala salah satu dari peserta didik diketahui pacaran atau hal yang menyimpang dari nilai-nilai yang telah ditanamkan, maka peserta didik tersebut akan dipanggil oleh pihak sekolah tapi bukan untuk dimarahi melainkan untuk digali lebih dalam alasan peserta didik tersebut melakukan hal yang dilarang itu.

Dalam menginternalisasi nilai religius sebagai bentuk pengejawantahan sila pertama pancasila yakni ketuhanan yang Maha Esa, maka pihak SIDH menggunakan pendekatan emosional sebagai sarana internalisasi nilai moral tersebut untuk memberikan pemahaman kepada peserta didik bahwa apa yang telah mereka lakukan tidak sesuai dengan ajaran agama dan tidak sesuai dengan nilai moral bangsa Indonesia yang berketuhanan. Negara Indonesia yang berpedoman pada ketuhanan Yang Maha Esa adalah suatu negara yang bukan negara atheis dan bukan pula negara kebangsaan yang chauvinistic, yang congkak dan sombong melainkan sebuah negara dan bangsa yang berdasar pada moral keagamaan dan kemanusiaan (Kaelan, 2014). Oleh sebab itu, pergaulan antar peserta didik di SIDH akan menjadi hal yang sangat krusial dan perlu diperhatikan. Dan dalam rangka meminimalisir kasus pergaulan bebas maka SIDH menggunakan pendekatan emosional agar peserta didik tidak merasa trauma ataupun takut atas perbuatannya dan bisa terbuka kepada para tenaga pendidik di SIDH tersebut.

b. Pendekatan Pengalaman

Pendekatan pengalaman adalah upaya pemasukan nilai-nilai kepada peserta didik dengan memberikan sebuah pengalaman langsung sehingga peserta didik dapat merasakan dan melakukan pemaknaan langsung atas apa yang dialaminya. Melalui pendekatan ini para siswa diberikan kesempatan untuk memperoleh pengalaman spiritualnya secara individual maupun kelompok (Muhtadi, 2007). Dalam kaitannya Sekolah Indonesia Den Haag, penanaman nilai 
dengan pengalaman dapat secara gamblang terlihat karena peserta didik langsung berhadapan dengan kondisi yang sangat jauh berbeda dengan Indonesia.

Peserta didik yang belajar di SIDH rata-rata berasal dari latar belakang keluarga yang berbeda. Sehingga, 3 bulan pertama peserta didik baru akan mengalami kesulitan, diantaranya: bahasa, attitude/perilaku, dan pemahaman pemikiran. Kesulitan tersebut, akan menjadi tantangan yang harus dihadapi oleh peserta didik baru. Oleh sebab itu, maka peran pendidik dalam tiga bulan masa adaptasi tersebut adalah sebagai Guide atau pembimbing. Belajar adalah suatu perubahan yang terjadi dalam diri organisme (manusia atau hewan) disebabkan oleh pengalaman yang dapat mempengaruhi tingkah laku organisme tersebut. Jadi, perubahan yang ditimbulkan oleh pengalaman tersebut baru dapat dikatakan belajar apabila mempengaruhi organisme (Nidawati, 2013).

Teori pengalaman yang dikemukakan di atas selaras dengan keadaan atau realitas yang terjadi di SIDH. Dengan iklim yang berbeda mulai dari budaya, kondisi geografis dan suasana di Belanda akan menjadikan peserta didik lebih mudah untuk belajar, menghayati dan melakukan refleksi atas pengalaman-pengalaman yang didapat disana. Hal ini dapat dilihat dari:

1) Menjalankan ibadah puasa mendorong siswa bermoral ketuhanan (religius)

Pada umumnya waktu menjalankan ibadah puasa di Indonesia adalah 8 jam. Tapi berbeda dengan di Belanda. Yang mana ketika musim panas berlangsung, waktu menjalankan ibadah puasa mencapai 18-20 jam perhari. Hal ini secara tidak langsung akan mendorong peserta didik untuk memiliki nilai religius sebagai bentuk pengejawantahan sila pertama pancasila yang termanifestasi dalam bentuk melaksanakan ajaran agama dengan baik.

2) Selektif memilih makanan dan minuman mendorong siswa bermoral ketuhanan (Religius)

Makanan yang ada di Den Haag sering kali mengandung Babi. Ataupun kalau ada daging sapi, biasanya tidak di sembelih. Kalau makan kentang, biasanya ada campuran minyak babi. Hal tersebut, tentu menjadi tantangan bagi para siswa untuk teliti dalam membedakan makanan yang halal dan haram, juga agar berhati-hati dan tidak jajan sembarangan. Yang mana hal tersebut membutuhkan bekal pengetahuan keagamaan yang cukup. Maka dari itu, peserta didik SIDH selalu diajarkan oleh guruya agar memilih makanan yang halal. Di samping itu antar peserta didik juga saling menghimbau dan mengingatkan mengenai makanan yang halal ataupun haram tersebut.

Pendekatan pengalaman mendorong siswa untuk selektif memilih makanan maupun minuman tidak hanya menelurkan nilai religius tapi juga nilai tanggung jawab. Terbukti dari bagaimana peserta didik saling mengingatkan sesamanya untuk berhati-hati dalam memilah makanan maupun minuman.

3) Menjadi minoritas mendorong siswa memiliki nilai toleransi dan humanisme yang tinggi

Sebagaimana diketahui bahwa mayoritas warga Belanda adalah atheis, maka muslim di Den Haag menjadi kaum minoritas, hal ini berimbas pada kelancaran beribadah sebab ketidakmudahan mencari akses tempat beribadah. Berbeda dengan di Indonesia, karena muslim menjadi mayoritas, maka di setiap daerah meskipun di perdesaan banyak didapati tempat ibadah. Kendati demikian, persoalan minoritas bukan menjadi kendala bagi pengelola untuk mendorong siswanya melaksanakan sholat tepat waktu. Karena SIDH telah memfasilitasi masjid yang telah di siapkan untuk umat Islam yang tinggal disana, meskipun jumlahnya sedikit dibandingkan dengan masjid yang ada di Indonesia. Salah satunya adalah masjid Al-Hikmah, masjid Indonesia yang dibangun di Den Haag dan dekat dengan kedutaan besar Republik Indonesia (KBRI). Masyarakat Belanda di sekitar SIDH tidak memberi penolakan bahkan mempersilakan untuk melaksanakan ritual agama dengan baik. Tentu dengan pengalaman ini, peserta didik akan banyak melakukan refleksi terkait bagaimana semestinya hidup berdampingan dengan masyarakat yang berbeda.

Jika ditilik dari falsafah pancasila sebagai pandangan moral bangsa, maka nilai toleran dan humanisme yang muncul ditengah-tengah peserta didik di Den Haag tidak jauh berbeda 
dengan inti isi sila pancasila kedua yang mengandung makna bahwa pada intinya manusia harus berbuat adil terhadap dirinya sendiri, manusia lain, masyarakat bangsa dan negara, lingkungannya serta adil terhadap Tuhan Yang Maha Esa. Konsekuensi dari nilai kemanusiaan yang adil dan beradab adalah menjunjung tinggi harkat dan martabat manusia sebagai makhluk Tuhan yang paling sempurna, menegakkan hak asasi manusia, dan menghargai perbedaan yang ada. Selain itu, manusia juga diharapkan memiliki sifat mencintai sesama serta mengamalkan nilai kemanusiaan dalam kesehariannya (Kaelan, 2014).

c. Pendekatan Keteladanan

Arti dari keteladanan yaitu segala sesuatu perbuatan yang baik untuk ditiru maupun dicontoh (Hidayat, 2015). Sedangkan pengertian dari pendekatan keteladanan adalah suatu cara bagi seorang pendidik dalam mendidik peserta didiknya melalui sebuah contoh teladan dengan harapan agar dapat ditiru dan dilaksanakan (Deden Supriyatna, 2018).

Proses penerapan metode keteladanan dapat dilakukan melalui dua cara yaitu secara langsung dan tidak langsung. Maksud dari penerapan metode keteladanan secara langsung yaitu seorang pendidik memposisikan dirinya sebagai contoh teladan yang baik dan pantas untuk ditiru bagi peserta didiknya. Sedangkan yang dimaksud dari penerapan metode keteladanan secara tidak langsung yaitu seorang pendidik memberikan contoh keteladanan bagi peserta didiknya melalui ilustrasi kisah-kisah keteladanan yang patut dicontoh, seperti kisah keteladanan para nabi (Taklimudin \& Saputra, 2018).

Pendidik merupakan figur terpenting dalam proses penerapan pendekatan keteladanan. Hal ini dikarenakan sosok pendidik dalam pandangan peserta didik merupakan sosok panutan dalam bersikap. Penting bagi pendidik memiliki sifat-sifat keteladanan yang baik sehingga nantinya dalam sikap atau perbuatan yang ditampilkan tercermin contoh-contoh teladan yang baik pula (Nur Ikhlas, 2013). Anak adalah peniru yang baik oleh sebab itu para pendidik diharapkan agar selalu memberikan atau mencontohkan teladan yang baik guna menciptakan anak didik yang baik pula.

Metode keteladanan (uswah hasanah) terhadap peserta didik, terutama anak-anak yang belum mampu berpikir kritis, akan banyak mempengaruhi pola tingkah laku mereka dalam perbuatan sehari-hari atau dalam mengerjakan suatu tugas pekerjaan yang sulit. Pendidik sebagai pembawa dan pengamal nilai-nilai agama, kultural dan ilmu pengetahuan akan memperoleh keefektifan dalam mendidik anak bila menerapkan metode ini. Keteladanan itulah kata yang mampu menggugah dan mendorong setiap peserta didik untuk menapaki jalan yang pernah dibuat oleh seorang pendidiknya (Mustofa, 2019).

Teori keteladanan ini selaras dengan realitas yang terjadi di SIDH. Bentuk keteladanan tersebut dapat kita lihat salah satunya berupa sikap toleransi. Pendidik memberikan contoh kepada peserta didik pentingnya sebuah toleransi termasuk dalam urusan hal beragama, dikarenakan di Belanda, Islam adalah agama minoritas maka sudah sepatutnya peserta didik yang ada di sana menghargai berbagai perbedaan yang ada. Selain itu pendidik juga memberikan teladan kepada peserta didiknya mengenai bagaimana sikap-sikap yang baik yang harus dimiliki seorang muslim. Hal ini bertujuan agar peserta didik tidak melakukan hal-hal yang dilarang oleh agama mengingat bahwasanya negara Belanda merupakan negara yang bebas dalam hal berperilaku.

d. Pendekatan Pembiasaan

Menurut Bahasa, pembiasaan berasal dari kata "biasa" yang berarti seperti yang sudahsudah, umum (lazim), dan termasuk sesuatu yang sudah tidak bisa dipisahkan dari kehidupan sehari-hari. Jika demikian maka arti pembiasaan menunjukkan sebuah proses, yang berarti proses menciptakan sesuatu atau seseorang menjadi terbiasa (Eko Nopriyadi, 2016). Selain itu Pembiasaan merupakan titik tombak dalam mengembangkan disiplin anak usia dini (Nurul Ihsani, 2018). 
Pendekatan pembiasaan adalah suatu sikap tertentu yang sifatnya otomatis, maksudnya tidak ada perencanaan atau pemikiran sebelumnya (Muhtadi, 2007). Pendekatan pembiasaan sangat nampak sekali dalam proses internalisasi nilai moral kepada peserta didik yang dilakukan di SIDH (Sekolah Indonesia Den Haag). Pendekatan ini digunakan oleh para pendidik di SIDH ketika mereka membentuk karakter dari para peserta didiknya. Contoh karakter yang ditekankan dalam pendekatan ini adalah adanya sikap jujur dan integritas tinggi. Untuk menginternalisasi nilai jujur hingga melekat pada diri peserta didik dibutuhkan usaha dari pendidik dalam membiasakan peserta didik untuk selalu bersikap jujur dalam segala hal. Proses internalisasi nilai moral melalui pendekatan pembiasaan akan berhasil jika disertai dengan contoh teladan yang baik dari si pendidik. Penggunaan pendekatan pembiasaan bisa menjadi efektif jika dipengaruhi oleh perkembangan kognitif dan perkembangan moral anak. Jika kebiasaan-kebiasaan baik sudah mulai diajarkan dan ditanamkan sejak dini, maka dalam hidupnya (berinteraksi sosial) akan tercermin bentuk-bentuk sikap yang baik pula (Aulianida et al., 2008). Usaha yang dilakukan oleh SIDH tersebut senada dengan pendapat yang dijelaskan oleh Imam Al-Ghazali bahwa perilaku atau akhlak yang tampil pada manusia merupakan sebuah perbuatan maupun tindakan yang terwujud secara langsung atau spontan tanpa adanya suatu pertimbangan untuk melakukannya (Rettolia, 2018). Namun perlu kita ketahui, bahwa hal tersebut tidak akan pernah bisa terwujud manakala tidak dilakukan melalui pembiasaan pada diri seseorang. Sehingga apabila hal tersebut dikaitkan dengan pendidikan, maka dapat kita pahami bahwa perilaku atau akhlak yang ada pada diri peserta didik hanya dapat terwujud apabila dilakukan melalui pendekatan pembiasaan. Lewat pembiasaan inilah, peserta didik diharapkan akan dapat melakukan hal-hal yang baik dengan tanpa adanya pertimbangan.

\section{SIMPULAN}

Sekolah Indonesi Den Haag (SIDH) meski tak bertempat di Indonesia bukan berarti ia tercabut dari akar tradisi. SIDH tetap menanamkan nilai-nilai moral seperti yang dilakukan pendidik kepada peserta didik yang ada di Indonesia. Nilai moral merupakan nilai yang menjadi tolok ukur baik atau buruk, yang mengatur perilaku dan pilihan seseorang dapat berasal dari pemerintah, masyarakat, agama, atau diri sendiri (hati nurani manusia). Nilai moral yang dikembangkan SIDH meliputi nilai nilai sosial, nilai keagamaan, serta nilai nasionalisme. Sedangkan Proses penanaman nilai moral di SIDH dilakukan melalui internalisasi. Upaya internalisasi nilai moral ini sangat penting untuk dilakukan oleh SIDH karena dengan begitu peserta didik akan tetap memiliki nilai-nilai moral sebagaimana yang telah menjadi adat istiadat bangsa Indonesia. Adapun proses internalisasi nilai moral yang dilakukan oleh SIDH, dalam hal ini penulis menyajikan proses internalisasinya melalui berbagai macam pendekatan diantaranya pendekatan emosional, pengalaman, keteladanan serta pendekatan pembiasaan.

\section{DAFTAR PUSTAKA}

Aisah, S. (2015). Nilai-Nilai Sosial yang Terkandung dalam Cerita Rakyat "Ence Sulaiman" pada Masyarakat Tomia. Jurnal Humanika, 3(15), 1689-1699.

Aulianida, D., Liestyasari, S. I., \& Ch, S. R. (2008). Metode pembiasaan untuk menanamkan akhlak pada anak di taman kanak-kanak islam terpadu (tkit) ar-raihan bantul. Journal of chemical information and modeling, 53(9), 7.

Boreza, L. (2015). Pendekatan Sosial dan Psikologi Untuk Menanamkan Nilai-Nilai Moral Pada Remaja. 1-96.

Darmiah, D. (2019). Strategi Pembelajaran Pendidikan Agama Islam di Sekolah Lanjutan Menengah Atas dan Pengaruhnya Terhadap Pembangunan Karakter. PIONIR: Jurnal Pendidikan, 53(9), 1689-1699.

Deden Supriyatna. (2018). Metode Keteladanan dalam Pendidikan Islam Menurut Abdurrahman An Nahlawi. Skripsi, 1O(2), 1-15.

Drajat, Z. (1996). Dasar-dasar Agama Islam pada Perguruan Tinggi Umum. Bulan Bintang.

Eko Nopriyadi. (2016). Penerapan Metode Pembiasaan Untuk Menanamkan Niai- Nilai 
Pendidikan Islam Pada Siswa Sd Negeri 38 Janna- Jannayya Kecamatan Sinoa Kabupaten Bantaeng. June, 9.

Hidayat, N. (2015). Metode Keteladanan dalam Pendidikan Islam. Ta'allum: Jurnal Pendidikan Islam, 3(2), 135-150. https://doi.org/10.21274/taalum.2015.3.2.135-150

Kaelan. (2014). Pendidikan Pancasila. Paradigma.

MASRUKHI. (2018). Internalisasi Nilai Moral Dalam Pembelajaran Era. Internalisasi Nilai Moral Dalam Pembelajaran Era Millenial, 1-4(1997), 15.

Muhammad Mahmud. (2018). Internalisasi Nilai-nilai Karakter dalam Meningkatkan Kompetensi Kepribadian Guru di SMPIT Al-Hidayah Sumenep. Skripsi, 25.

Muhtadi, A. (2007). Teknik Dan Pendekatan Penanaman Nilai Dalam Proses Pembelajaran Di Sekolah. Majalah Ilmiah Pembelajaran, 3(1), 60-69.

Mustofa, A. (2019). Metode Keteladanan Perspektif Pendidikan Islam. CENDEKIA : Jurnal Studi Keislaman, 5(1). https://doi.org/10.37348/cendekia.v5i1.71

Nidawati. (2013). Belajar Dalam Prespektif Psikologi Dan Agama. PIONIR: Jurnal Pendidikan, 84, 487-492. http://ir.obihiro.ac.jp/dspace/handle/10322/3933

Noor, T. (2018). Rumusan Tujuan Pendidikan Nasional Pasal 3 Undang-Undang Sistem Pendidikan Nasional No 20 Tahun 2003. Wahana Karya Ilmiah, 3(01), 123-144.

Nur Ikhlas. (2013). Penggunaan Metode Keteladanan Dalam Pembinaan Akhlak Siswa r. 2(1), 10.

Nurul Ihsani. (2018). Hubungan Metode Pembiasaan Dalam Pembelajaran Dengan Disiplin Anak Usia Dini. Jurnal Ilmiah Potesnia, 3(1), 51.

Pujiastuti, S. (2015). Pendidikan Karakter Melalui Seni Musik: Analisis Lirik Tembang ( Lagu ) Dolanan Anak-Anak Jawa Skripsi Program Study Pendidikan Agama Islam ( Pai ) Fakultas Tarbiyah Dan Ilmu Keguruan ( Ftik) Purwokerto.

Sanusi, A. (2017). Pendidikan untuk Kearifan (2nd ed.). Nuansa Cendekia.

Suyatno. (2012). Nilai, norma, moral, etika dan pandangan hidup perlu dipahami oleh setiap warga negara dalam kehidupan berbangsa dan bernegara. PKn Progresif, 7(1), 34-44.

Taklimudin, T., \& Saputra, F. (2018). Metode Keteladanan Pendidikan Islam dalam Persfektif Quran. BELAJEA: Jurnal Pendidikan Islam, 3(1), 1. https://doi.org/10.29240/bjpi.v3i1.383Zulkarnain. (2019). Emosional : Tinjauan Al- Qur ' an dan Relevansinya Dalam Pendidikan. 5(2), 89-100. 